\title{
Presynaptic Enhancement of Inhibitory Synaptic Transmission by Protein Kinases $A$ and $C$ in the Rat Hippocampus in vitro
}

\author{
Marco Capogna, Beat H. Gähwiler, and Scott M. Thompson \\ Brain Research Institute, University of Zurich, $\mathrm{CH}-8029$ Zurich, Switzerland
}

The protein kinase $C$ activator phorbol 12,13-dibutyrate $(0.5$ $\mu \mathrm{M}, \mathrm{PDBu}$ ) and the protein kinase $\mathrm{A}$ activator forskolin (20 $\mu \mathrm{M})$ each increased evoked monosynaptic inhibitory postsynaptic current (IPSC) amplitude, without affecting its reversal potential, and increased the frequency of miniature IPSCs (mIPSCs), without affecting their amplitude or kinetics, as assessed with whole-cell recording from CA3 pyramidal cells in hippocampal slice cultures. The effects of forskolin and PDBu on both evoked IPSC amplitude and mIPSC frequency were additive and were antagonized by inhibitors of protein kinases $A$ and $C$, respectively. The kinase activatorinduced increases in mIPSC frequency were quantitatively comparable to the increases in evoked IPSC amplitude. The increases in mIPSC frequency were not attenuated by the voltage-dependent calcium channel blocker $\mathrm{Cd}^{2+}(100 \mu \mathrm{M})$.

We conclude that stimulation of protein kinases $A$ and $C$ potentiates hippocampal inhibitory synaptic transmission through independent presynaptic mechanisms of action. Kinase-induced potentiation of spontaneous release does not require modulation of axon terminal $\mathrm{Ca}^{2+}$ channels. This mechanism may also contribute substantially to the potentiation of evoked release.

[Key words: forskolin, phorbol ester, GABA, phosphorylation, protein kinase, transmitter release]

Modulation of function is often mediated by protein kinasecatalyzed phosphorylation of cellular substrates, such as ion channels, receptors, or cytoskeletal elements. The actions of presynaptic protein kinases in the modulation of transmitter release are particularly important in the nervous system (Greengard et al., 1993) and are probably involved in short- and longterm synaptic plasticity (Malenka and Nicoll, 1993). Physiological studies of presynaptic kinases in the mammalian brain are limited by access to the enzymes. In particular, the protein kinases $A$ and $C$ can be readily and selectively activated with extracellularly applied substances.

Protein kinase $\mathrm{C}$ (PKC) consists of a family of isozymes sensitive to diacylglycerol and, typically, to intracellular $\mathrm{Ca}^{2+}$ (Nishizuka, 1988). Tumor-promoting phorbol esters mimic the

\footnotetext{
Received May 16, 1994; revised July 5, 1994; accepted Aug. 2, 1994.

We thank Ms. L. Rietschin for preparing cultures, Mr. R. Schöb for photographic assistance, and Drs. E. D'Angelo, U. Gerber, and M. Scanziani for their comments on the manuscript. Software was generously provided by Dr. S. Traynellis for the analysis of mIPSC kinetics, by Dr. C. Staub for the Kolmogorov-Smirnov test, and by Dr. P. Vincent for the analysis of mIPSC frequency. This work was supported by the Swiss National Science Foundation (31-27641.89) and the Dr. Eric Slack-Gyr Foundation.

Correspondence should be addressed to Marco Capogna at the above address. Copyright (C) 1995 Society for Neuroscience 0270-6474/95/151249-12\$05.00/0
}

physiological activator diacylglycerol by inducing a translocation of PKC from cytoplasmic to membrane compartments, and can, therefore, be experimentally used to activate the enzyme (Kraft and Anderson, 1983). The hippocampus displays a specific distribution of $\mathrm{PKC}$ isoforms in in situ hybridization experiments (McGinty et al., 1991) and contains many phorbol ester binding sites (Worley et al., 1986).

Protein kinase A (PKA), another family of serine/threonine kinases, is activated by intracellular cyclic adenosine monophosphate (cAMP). The diterpene forskolin, and some of its derivatives, bind to the catalytic subunit of adenylyl cyclase, resulting in a significant increase in the intracellular cAMP concentration, and can, thus, be used to stimulate protein kinase A. The hippocampus exhibits high levels of both PKA expression (Cadd and McKnight, 1989) and forskolin binding sites (Gehlert et al., 1985).

Application of phorbol esters produces a considerable enhancement of evoked and spontaneous excitatory transmitter release from hippocampal pyramidal cells by stimulating protein kinase C (Malenka et al., 1986, 1987; Segal, 1989; Finch and Jackson, 1990). This effect is accompanied by an increase in the value of the mean number of quanta released, but no change in quantal amplitude (Yamamoto et al., 1987), demonstrating a presynaptic locus of action. It is not yet clear whether this action results from a direct modulation of the exocytotic process or rather occurs secondarily as a result of modification of some other process, such as voltage-dependent $\mathrm{Ca}^{2+}$ influx into the terminal (cf. Malenka et al., 1987; Finch and Jackson, 1990; Parfitt and Madison, 1993). Likewise, forskolin has been shown to potentiate excitatory transmitter release from mossy fiber terminals in area CA3 (Hopkins and Johnston, 1988; Weisskopf et al., 1993) and from Schaffer collateral/commissural terminals in area CAl (Chavez-Noriega and Stevens, 1994).

While the actions of protein kinases on excitatory synapses are well studied because of their potential involvement in longterm potentiation (Malenka and Nicoll, 1993), relatively little is known of their role in inhibitory synaptic transmission. The amino acid sequences of several subunits of the $\mathrm{GABA}_{\mathrm{A}}$ receptor display putative sites for phosphorylation by both $\mathrm{PKC}$ and PKA (for review, Raymond et al., 1993). In the cerebellum, activation of PKA potentiates the presynaptic release of GABA and decreases the sensitivity of postsynaptic $\mathrm{GABA}_{\mathrm{A}}$ receptors in some stellate cells (Llano and Gerschenfeld, 1993). The effect of PKC activation on $\mathrm{GABA}_{\mathrm{A}}$ receptor-mediated synaptic events in the hippocampus has received only modest attention (Lambert and Teyler, 1991; Pitler and Alger, 1992), and the effect of PKA activation is unknown. Phorbol esters are also known to impair pre- and postsynaptic $\mathrm{GABA}_{B}$ receptor-mediated inhibition in the hippocampus (Dutar and Nicoll, 1988). 
A

\section{MONOSYNAPTIC IPSCs}
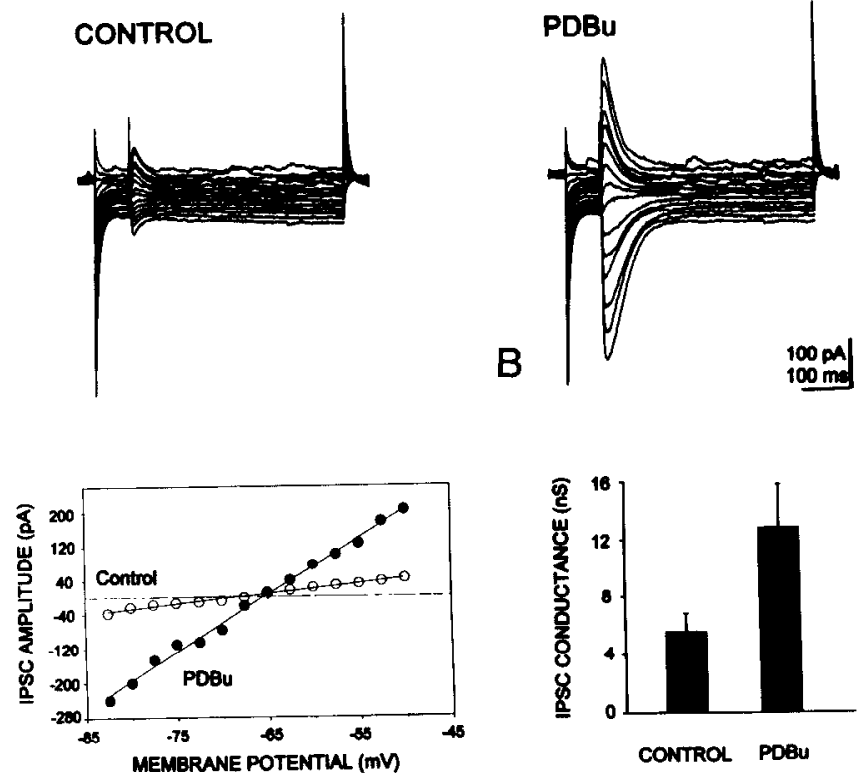

Figure 1. The phorbol ester PDBu selectively enhances IPSC conductance. $A$, Monosynaptic $\mathrm{GABA}_{\mathrm{A}}$ receptor-mediated IPSCs recorded while stepping to several membrane potentials between -82.5 and $-50 \mathrm{mV}$ from the holding potential of $-55 \mathrm{mV}$, before (left) and after 6 min of $0.5 \mu \mathrm{M}$ PDBu application (right). IPSCs elicited by stimulation close (< $300 \mu \mathrm{m})$ to the CA3 pyramidal cell in the presence of AP5 and CNQX (20 $\mu \mathrm{M}$ each). The amplitude of the individual IPSCs are plotted below (left ) as a function of the membrane potential at which they were elicited. The calculated $E_{1 p s c}$ was $-68 \mathrm{mV}$ before, and $-65 \mathrm{mV}$ during PDBu application, whereas the measured IPSC conductance $\left(\mathrm{g}_{\mathrm{IPSC}}\right)$ increased from 2.3 to $13.6 \mathrm{nS}$. All data from the same cell. Potassium gluconate electrode. $B$, Pooled data from five cells.

In the present study, we characterized the actions of the kinase activators phorbol ester and forskolin on $\mathrm{GABA}_{\mathrm{A}}$ receptor-mediated currents in area CA3 of hippocampal slice cultures. In particular, we have examined possible pre- and postsynaptic actions, attempted to establish that their effects are mediated by the appropriate kinases, and tested the role of voltage-dependent $\mathrm{Ca}^{2+}$ channels in mediating their presynaptic actions. Furthermore, we assessed whether the two compounds exerted their effects via phosphorylation of independent sites by means of occlusion experiments.

A preliminary report has been presented in abstract form (Capogna et al., 1993b).

\section{Materials and Methods}

Organotypic slice cultures were prepared according to the previously described procedure (Gähwiler, 1981; Gähwiler et al., 1991). Briefly, rat pups (5-6 d old) were killed by decapitation and the hippocampi were removed under sterile conditions. At the time of explantation, most slices were X-irradiated ( $900-1200$ roengten) to depress glial proliferation and, thus, increase the ease of seal formation with patch-clamp electrodes. Slices were attached to glass coverslips with clotted chicken plasma. The coverslips were then placed in test tubes containing semisynthetic medium, and the test tubes were placed on a rollerdrum in an incubator. After 2 weeks in vitro the slices become thinned to one to two cell layers in thickness, yet contain numerous GABAergic neurons that form appropriate synapses on the soma and dendrites of CA3 pyramidal cells (Streit et al., 1989).

Electrophysiology, data analysis, and drugs. After 2-4 weeks in vitro, the cultures were placed in a recording chamber $(0.6 \mathrm{ml}$ volume $)$, mount- ed on an inverted microscope, and superfused with an extracellular solution consisting of (in $\mathrm{mM}$ ) $137 \mathrm{NaCl}, 2.7 \mathrm{KCl}, 2.8 \mathrm{CaCl}_{2}, 2 \mathrm{MgCl}_{2}$, $11.6 \mathrm{NaHCO}_{3}, 0.4 \mathrm{NaH}_{2} \mathrm{PO}_{4}$, and 5.6 glucose. The $\mathrm{pH}$ was 7.4 , as monitored with Phenol Red $(10 \mathrm{mg} / \mathrm{l})$, and the temperature was held constant at $25^{\circ} \mathrm{C}$. Monosynaptic IPSCs were evoked with monopolar stimuli $(0.1 \mathrm{msec},-10$ to $-30 \mu \mathrm{A})$ delivered through a second patch pipette filled with $155 \mathrm{~mm} \mathrm{NaCl}$ and placed $<300 \mu \mathrm{m}$ from the recorded cell in the presence of high concentrations of excitatory amino acid receptor antagonists (Davies et al., 1990).

CA3 pyramidal cells were visually identified and recorded by means of the whole-cell voltage-clamp technique. Borosilicate glass capillaries (1.5 $\mathrm{mm}$ o.d., $1.17 \mathrm{~mm}$ i.d.) were pulled in two stages to a resistance of about 2-4 M $\Omega$. The intracellular solutions were (in $\mathrm{mM}$ ) 140 potassium gluconate (or $\mathrm{KCl}$ plus $1 \mathrm{~mm} \mathrm{QX}-314$ ), $10 \mathrm{KCl}, 5$ HEPES, $2 \mathrm{MgCl}_{2}, 2$ EGTA, for the recording of evoked inhibitory synaptic currents (IPSCs) or, for spontaneous miniature inhibitory synaptic currents (mIPSCs), $140 \mathrm{CsCl}, 5 \mathrm{HEPES}, 2 \mathrm{MgCl}_{2}$, and 2 EGTA or BAPTA. Both solutions were titrated to $\mathrm{pH} 7.3$ with $\mathrm{KOH}$. Membrane currents were amplified $(2-10 \mathrm{mV} / \mathrm{pA})$, filtered and digitized at $2 \mathrm{kHz}$. In experiments in which the mIPSC time course was studied, data were digitized at $10 \mathrm{kHz}$. All recordings of spontaneous mIPSCs were performed at a holding potential of $-70 \mathrm{mV}$. Series resistance (typically between 10 and $30 \mathrm{M} \Omega$ ) was regularly checked during experiments. Data were not considered if increases in series resistance caused significant reductions in MIPSC amplitude (see below). In order to study responses to exogenous GABA without introducing $\mathrm{Ca}^{2+}$ chelators, single-electrode voltage-clamp recordings were performed with sharp microelectrodes containing $1 \mathbf{M}$ $\mathrm{KCl}$. The switching voltage frequency was $1-2 \mathrm{kHz}$. Capacitance neutralization, gain and phase were adjusted to produce optimal clamp efficiency.

Spontaneous mIPSCs were examined as previously described (Scanziani et al., 1992). In brief, mIPSCs were recorded in several epochs of $102 \mathrm{sec}$ in duration for each experimental condition. mIPSCs were detected off line by a computer program that calculated the first derivative of the current trace, and detected events that exceeded an arbitrary threshold (typically set at 8-15 pA, and held constant for each experiment) for a minimum length of time $(1.5 \mathrm{msec})$. With this threshold, no events were detected by the program in the presence of $40 \mu \mathrm{M}$ bicuculline. The analysis of mIPSCs was performed with cumulative probability plots, which make no assumption about the distribution of events. The amplitude and interevent interval distributions were compared using the Kolmogorov-Smirnov test, which estimates the probability ( $p$ ) that two distributions are similar (Van der Kloot, 1991). With this test, two cumulative sets of data were considered not significantly different only when $p>0.02$. The time course of decay of individual mIPSCs was computer fitted with a single exponential. Numerical values are provided as mean standard error of the mean.

All drugs, except GABA, were bath applied and reached a steadystate concentration in the chamber in $<2 \mathrm{~min}$. GABA $(50 \mathrm{~mm}, \mathrm{pH}=$ 4.5) was iontophoretically applied (cathodal current $=5-40 \mathrm{nA}$ ) from a pipette positioned close to the recorded cell. Small anodal retaining currents were employed between ejections and CGP 35348 was used to block $\mathrm{GABA}_{\mathrm{B}}$ receptors. The following compounds were used: $\gamma$ aminobutyric acid (GABA), phorbol 12,13-dibutyrate (PDBu), phorbol-

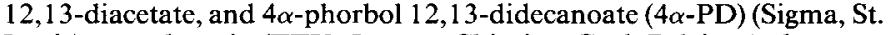
Louis); tetrodotoxin (TTX, Janssen Chimica, Geel, Belgium); 6-cyano7-nitroquinoxaline-2,3-dione (CNQX) and D-2-amino-5-phosphonovalerate (AP5) (Tocris Neuramin, Bristol, UK); staurosporin (Boehringer-Mannheim, Germany); $N$-(2,6-dimethylphenylcarbamoylmethyl) triethylammonium bromide (QX-314) (Alamone Labs, Jerusalem, Israel); P-[3-aminopropyl]-P-diethoxymethylphosphinic acid (CGP 35348 , a gift of Ciba Geigy, Basel, Switzerland); $7 \beta$-deacetyl- $7 \beta-(\gamma-N$-methylpiperazino) butyryl forskolin (forskolin), 1,9-dideoxyforskolin, Rp-cyclic adenosine monophosphate (Rp-cAMP), and 1-[N,O-bis(1,5-isoquinolinesulfonyl)- $N$-methyl-L-tyrosyl]-4-phenyl-piperazine (KN-62) (LC Laboratories, Woburn, MA). Bicuculline methochloride (bicuculline in the text) was prepared from Fluka bicuculline. Applications of Rp-cAMP and staurosporin (when $>1 \mathrm{hr}$ ) were performed by adding the substances to the culture media before obtaining recordings.

\section{Results}

Phorbol esters potentiate evoked inhibitory synaptic currents The action of phorbol esters on evoked monosynaptic IPSCs was studied using whole-cell recording from CA3 pyramidal 


\section{mIPSCs}

\section{CONTROL}
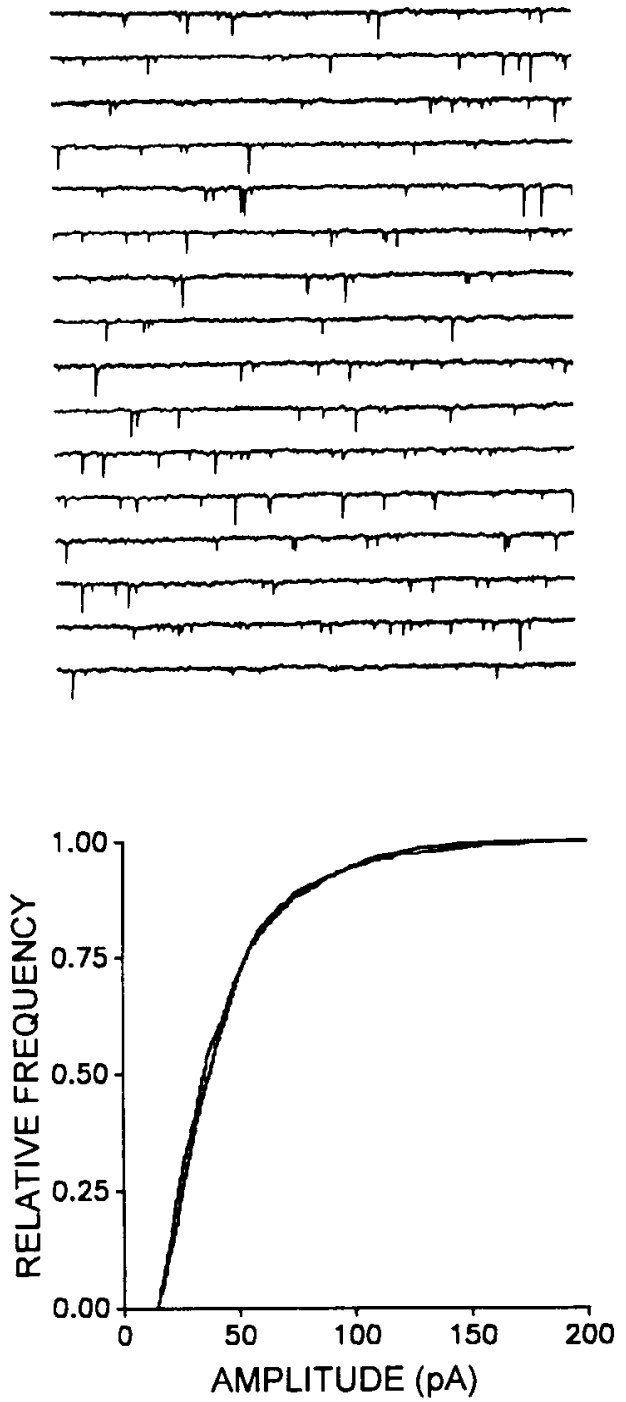

\section{PDBu}
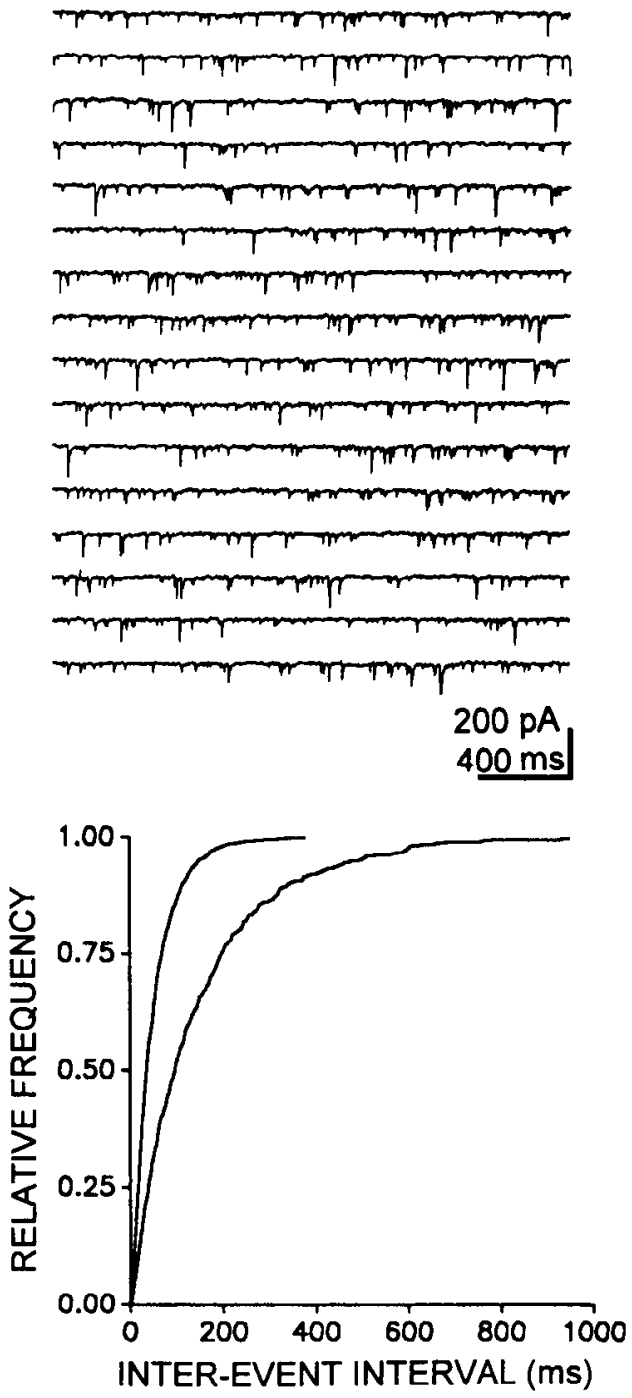

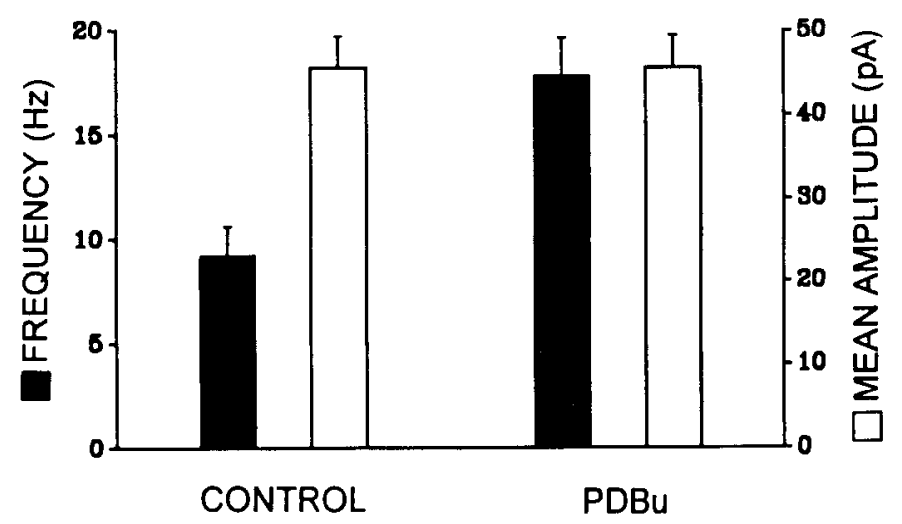

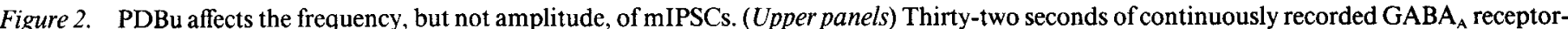
mediated mIPSCs in the presence of TTX $(0.5 \mu \mathrm{M})$, CNQX $(20 \mu \mathrm{M})$, and AP5 $(20 \mu \mathrm{M})$. Bath application of PDBu $(0.5 \mu \mathrm{M})$ increased the frequency of mIPSCs from $6.8 \mathrm{~Hz}$ (left) to $19.5 \mathrm{~Hz}$ (right) without affecting the mean amplitude (44.2 vs. $44.3 \mathrm{pA})$. Cumulative amplitude distribution (left), and cumulative frequency distribution (right) of mIPSCs for this cell are shown below. PDBu had no effect on the amplitude distribution ( $p>0.1$, Kolmogorov-Smirnov test; number of events analyzed $=696$ and 1985), but shifted the frequency distribution to the left towards shorter interevent intervals. (Lower graph) Pooled data from 19 cells showing that PDBu increased the frequency of mIPSCs, but did not affect their amplitude. 

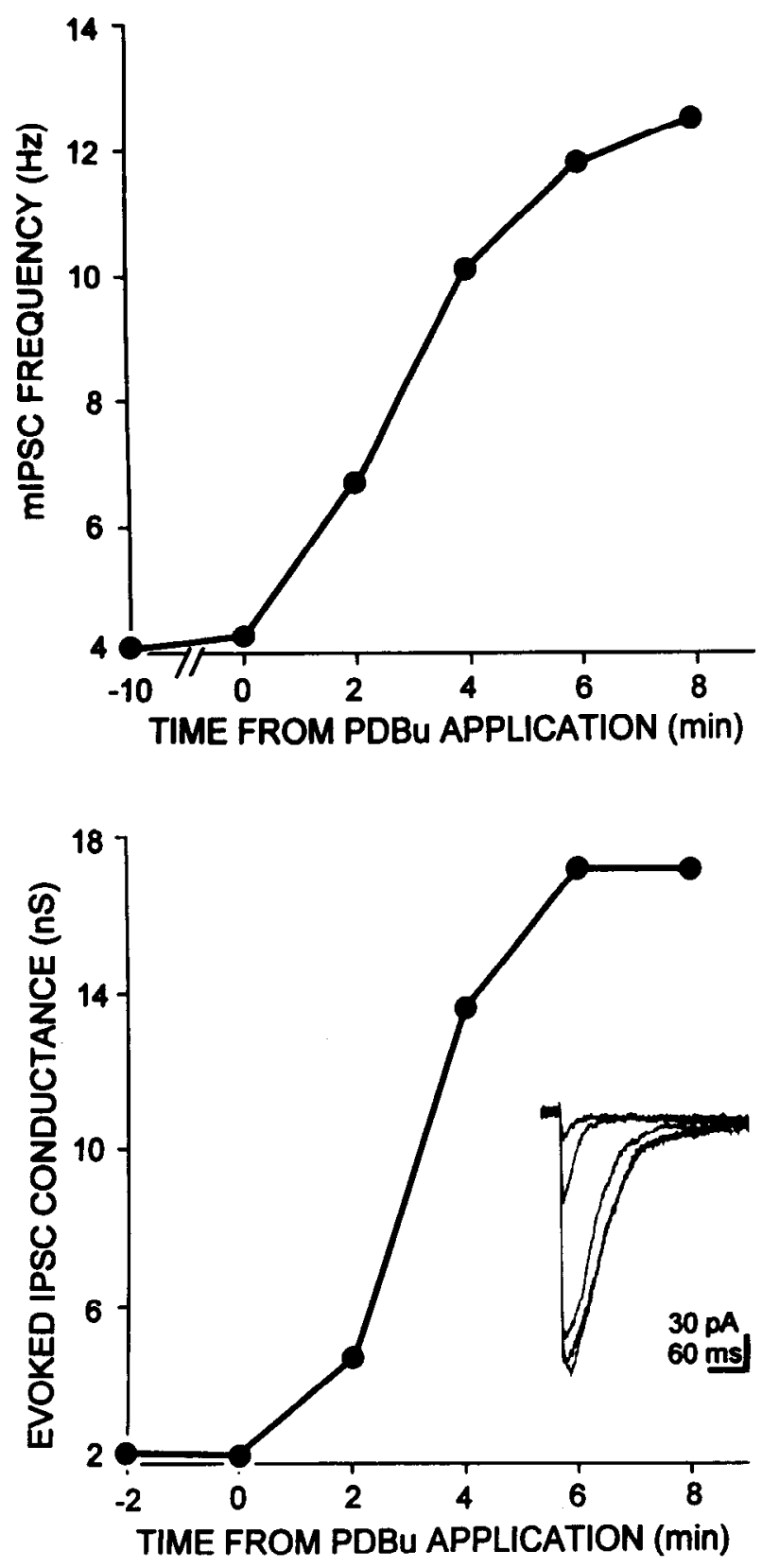

Figure 3. The time course of PDBu action is comparable for mIPSC frequency and evoked IPSC amplitude. The effects of PDBu on spontaneous mIPSC frequency (upper) and evoked IPSC amplitude in another cell (lower, shown in insert) reached a steady-state level about 6 min after PDBu entered the recording chamber. Recording conditions as for Figures 1 and 2.

cells. Local stimulation in the presence of the excitatory amino acid receptor antagonists 6-cyano-7-nitroquinoxaline-2,3-dionc (CNQX) and D-2-amino-5-phosphonovalerate (AP5) (20 $\mu \mathrm{M}$ each) produced monosynaptic IPSCs that were fully abolished by bicuculline $(40 \mu \mathrm{M})$, indicating that they were mediated solely by $\mathrm{GABA}_{\mathrm{A}}$ receptors. Bath application of $0.5 \mu \mathrm{M}$ phorbol 12,13dibutyrate $(\mathrm{PDBu})$ enhanced monosynaptic IPSC amplitude. Current-voltage plots were obtained for calculation of the reversal potential and underlying conductance (Fig. $1 A$ ). On average, the IPSC conductance was increased to $269 \pm 76 \%$ of control (from $5.6 \pm 1.1 \mathrm{nS}$ to $12.8 \pm 2.7 \mathrm{nS}$ ) (Fig. $1 B$ ), whereas the reversal potential was $-70.6 \pm 1.0 \mathrm{mV}$ before and -69.7 $\pm 1.5 \mathrm{mV}$ in the presence of PDBu, respectively $(n=5)$. The potentiation of IPSC conductance was significant $(p<0.05$, paired two-tailed $t$ test) and was irreversible. A complete recovery of potentiated inhibitory responses could be observed, however, by using the less lipophilic phorbol ester, phorbol12,13-diacetate $(2-3 \mu \mathrm{M})(n=4$, not shown).

Postsynaptic $\mathrm{GABA}_{\mathrm{A}}$ receptor sensitivity was examined by recording inward currents elicited with iontophoretically applied GABA, using single-electrode voltage-clamp with sharp $\mathrm{KCl}$-filled microelectrodes in medium containing excitatory amino acid and $\mathrm{GABA}_{\mathrm{B}}$ receptor antagonists and TTX. At a time when the PDBu had fully blocked the slow calcium-dependent afterhyperpolarizing current, there was no significant effect on GABA responses (not shown), even with applications $>15 \mathrm{~min}$. On average, the amplitude of the GABA current was $96 \pm 3 \%$ of control in the presence of $\operatorname{PDBu}(n=6)$.

\section{Phorbol esters increase mIPSC frequency}

mIPSCs result from the spontaneous, action potential-independent fusion of individual GABA-containing vesicles at active zones in the axon terminals of interneurons. Their frequency and amplitude distribution can be used to examine postsynaptic receptor sensitivity and the presynaptic transmitter release process, provided changes occur at all terminals. In the presence of CNQX, AP5, and TTX, whole-cell voltage-clamp recordings at $-70 \mathrm{mV}$ revealed mIPSCs occurring at a frequency of 5-15 $\mathrm{Hz}$, which were abolished by bicuculline $(40 \mu \mathrm{M})$, demonstrating that they were mediated solely by $\mathrm{GABA}_{\mathrm{A}}$ receptors (see Fig. 41). Bath application of $\mathrm{PDBu}(0.5 \mu \mathrm{M})$ greatly increased the frequency of mIPSCs (Fig. 2), but had no effect on the distribution of their amplitudes, indicating a presynaptic site of action. On average, mIPSC frequency was significantly increased to $233 \pm 24 \%$ of control $(p<0.0001$, paired two-tailed $t$ test, $n=19$ ), whereas the mean mIPSC amplitude in these experiments was $100 \pm 1 \%$ of control in the presence of PDBu. The time course of the PDBu effects on mIPSC frequency and evoked IPSC conductance were comparable (Fig. 3). Both effects reached a steady-state level about $6 \mathrm{~min}$ after the arrival of PDBu in the recording chamber.

\section{The effects of $P D B$ u are mediated by protein kinase $C$}

A number of studies have described actions of phorbol esters that are not mediated by protein kinase $\mathrm{C}$ (Wilkinson and Hallam, 1994). We, therefore, performed the following controls.

Bath application of $1 \mu \mathrm{M} 4 \alpha$-PD, a phorbol ester that does not activate $\mathrm{PKC}$, did not significantly affect the frequency or amplitude of mIPSCs (mean mIPSC frequency $=119 \pm 11 \%$ of control, $n=6, p>0.1$ paired two-tailed $t$ test). Application of $0.001 \%$ ethanol alone, used to dissolve the phorbol esters, also had no effect on mIPSC's (not shown).

The effect of PDBu on inhibitory synaptic transmission was attenuated by the protein kinasc inhibitor staurosporin $(1-3 \mu \mathrm{M}$, 0.5-8 hr) (Rüegg and Burgess, 1989). This action was somewhat variable, and was increased with longer durations of application. PDBu increased IPSC amplitude only to $164 \pm 38 \%(n=4)$ of control in the presence of staurosporin (as compared to $256 \%$ in untreated cultures) (Fig. $4 C$ ). Staurosporin also reduced the ability of $\mathrm{PDBu}$ to increase mIPSC frequency to a similar extent (Fig. 4A,B). On average, PDBu increased mIPSC frequency only by $160 \pm 15 \%(n=10)$ in the presence of staurosporin, significantly different from the effect observed in control cultures (233\%, see above) ( $p<0.05$, unpaired two-tailed $t$ test), and 


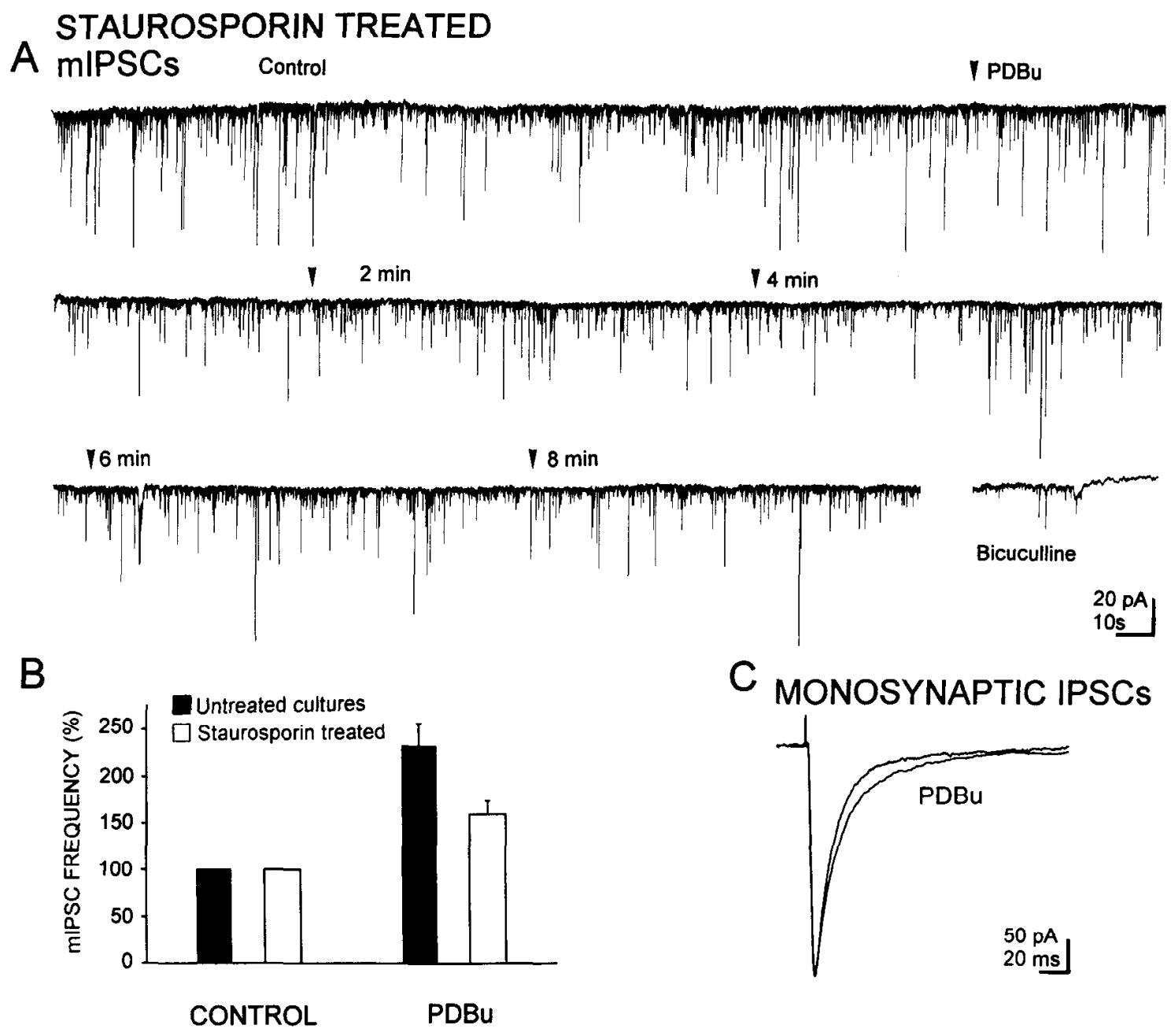

Figure 4. Staurosporin reduces the effect of PDBu on mIPSC frequency and evoked EPSC amplitude. $A$, Continuous chart recording of mIPSCs before and after bath application of $0.5 \mu \mathrm{M}$ PDBu in a culture treated $8 \mathrm{hr}$ with $1 \mu \mathrm{M}$ staurosporin. The PDBu-induced increase in mIPSC frequency was completely prevented in this cell. mIPSC frequency was control $=8.5 \mathrm{~Hz}, \mathrm{PDBu} 2 \mathrm{~min}=7.4 \mathrm{~Hz}, 4 \mathrm{~min}=6.6 \mathrm{~Hz}, 6 \mathrm{~min}=6.2 \mathrm{~Hz}, 8 \mathrm{~min}=$ $8 \mathrm{~Hz}, p>0.02$ (Kolmogorov-Smirnov test) for comparisons between control and all subsequent segment of recordings. $B$, Pooled data from 10 cells. In the presence of staurosporin, the PDBu-induced increase in mIPSC frequency is significantly less than in untreated cultures $(p=0.001$, two-tailed $t$ test). $C$, The effect of PDBu on evoked IPSC amplitude is blocked in a culture previously incubated with staurosporin (3 $\mu \mathrm{M}, 4 \mathrm{hr}$ ). $\mathrm{KCl}$-containing electrode, holding potential $=70 \mathrm{mV}$.

remarkably similar to the partial block of the effect of PDBu on evoked IPSC. Staurosporin was, thus, less effective in preventing the action of PDBu on inhibitory synaptic transmission than that preventing other pre- and postsynaptic PDBu-induced effects in hippocampal slice cultures (Sim et al., 1992; Capogna et al., 1993a).

It has been suggested that the potentiating action of phorbol esters might be mediated indirectly by $\mathrm{Ca}^{2+} /$ calmodulin (CaM)dependent protein kinase II (Wang et al., 1988). The CaM kinase II antagonist KN-62 (5 $\mu \mathrm{M})$ (Tokumitsu et al., 1990) did not reduce the ability of PDBu to increase mIPSC frequency $(n=$ $5)$. It should be noted, however, that we were unable to obtain a positive control for the block of CaM kinasc II by KN-62.

Taken together, these data indicate that phorbol esters specifically activate intraterminal PKC to enhance the evoked and spontaneous release of GABA from hippocampal interneurons.

Forskolin increases evoked IPSC amplitude and mIPSC frequency by stimulating $P K A$

The modulation of GABAergic inhibition induced by activation of PKA was studied by means of the water-soluble adenylyl cyclase activator: $7 \beta$-deacetyl- $7 \beta-(\gamma-N$-methylpiperazino $)$ butyryl forskolin (referred to as forskolin) (Laurenza et al., 1987). Forskolin $(20 \mu \mathrm{M})$ increased the amplitude of evoked monosynaptic IPSCs (see Fig. $8 B)$ to $180 \pm 12 \%$ of control $(n=6, p<$ 0.05 , paired two-tailed $t$ test). This effect was found to result solely from an increase in IPSC conductance from $6.2 \pm 0.4 \mathrm{nS}$ to $10.9 \pm 2.5 \mathrm{nS}(n=3)$, without any change in the IPSC reversal potential $(-70.5 \pm 4.8 \mathrm{mV}$ and $-69.7 \pm 6 \mathrm{mV}, n=3)$. This action of forskolin was reduced in cultures previously incubated with the competitive cAMP antagonist Rp-cAMP (200-500 $\mu \mathrm{M}$ for 90-120 min) (Rothermel and Botelho, 1988). Under these conditions, forskolin increased IPSC amplitude to only $138 \pm$ $17 \%$ of the control $(n=4$, Fig. $8 C)$. The decreascd effectiveness of forskolin in Rp-cAMP-treated cultures was significant ( $p<$ 0.05 , paired two-tailed $t$ test).

Forskolin $(20 \mu \mathrm{M})$ also produced a consistent increase in mIPSC frequency without changing the MIPSC amplitude distribution (Fig. 5A), much like PDBu. On average, mIPSC amplitude was $103 \pm 3 \%$ of control during forskolin application, whereas mIPSC frequency increased significantly to $182 \pm 10 \%$ of control $(\rho<$ 0.001 , paired two-tailed $t$ test, $n=10$ ). This concentration was 
A

mIPSCs CONTROL
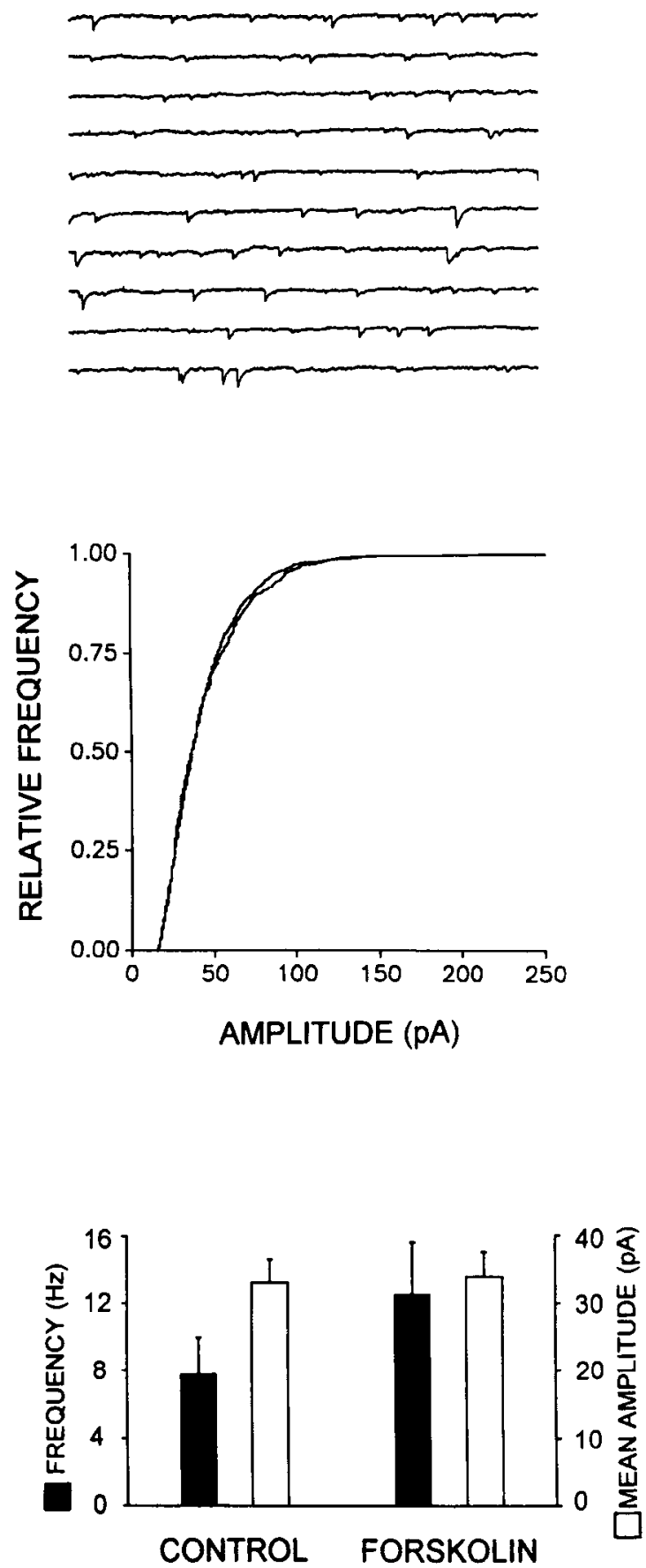

\section{FORSKOLIN}
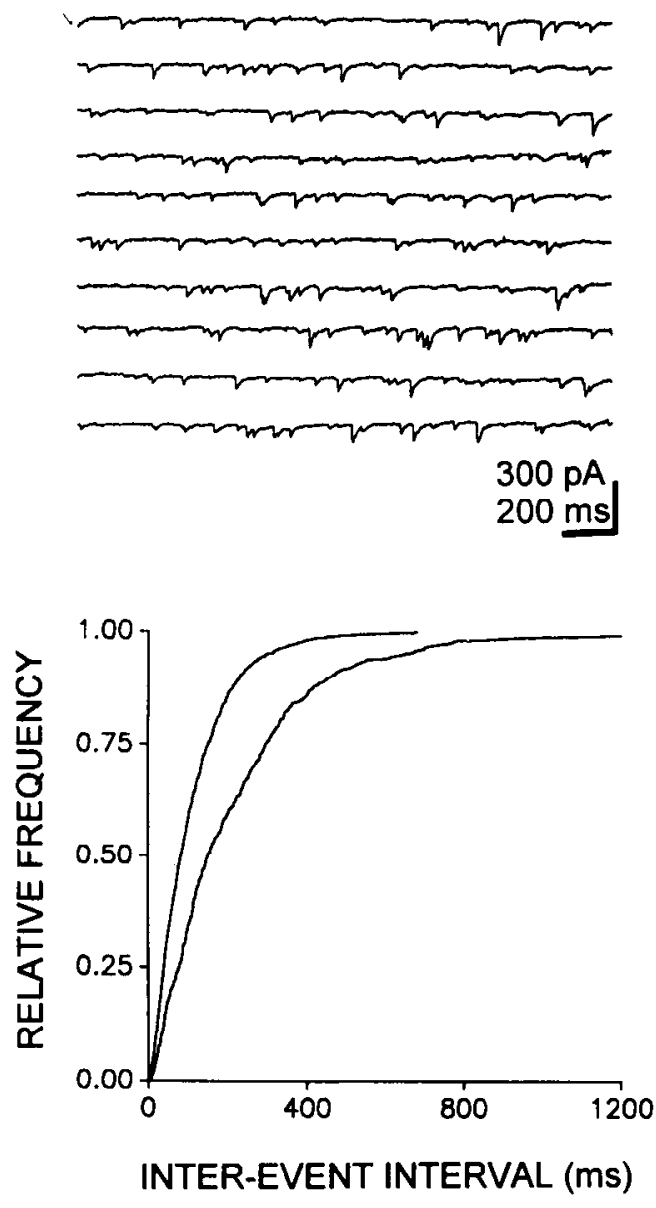

$\mathrm{B}$

\section{FORSKOLIN}

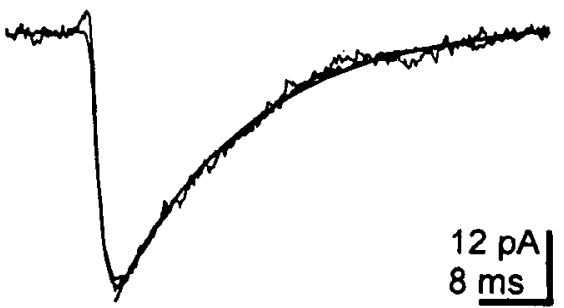

Figure 5. Forskolin affects the frequency, but not the amplitude or kinetics, of mIPSCs. A, (Upper row) Twenty milliseconds of continuously recorded GABA $\mathrm{A}_{\mathrm{A}}$ receptor-mediated mIPSCs. Bath application of forskolin $(20 \mu \mathrm{M})$ increased the frequency of mIPSCs from $4.7 \mathrm{~Hz}(l e f t)$ to $9 \mathrm{~Hz}$ (right) without affecting the mean amplitude ( $45.8 \mathrm{vs} .43 .7 \mathrm{pA}$ ). Cumulative amplitude $(l e f t)$ and frequency distributions (right) for mIPSCs in this cell are shown below. Forskolin had no significant effect on the amplitude distribution $(p>0.5$, Kolmogorov-Smirnov test; number of events analyzed $=478$ and 919), but shifted the frequency distribution to the left towards shorter interevent intervals. (Lower row) Pooled data showing that forskolin increases in mIPSC frequency without affecting mean mIPSC amplitude $(n=10)$. $B$, Averages of 50 mIPSCs in this cell before and after application of forskolin are shown superimposed with the exponential fit of their decay phase at lower left. Fitted time constants were 14.4 msec both before and during forskolin application. 
found to produce the maximal effect, as subsequent application of $40 \mu \mathrm{M}$ forskolin further increased mIPSC frequency only 13 $\pm 10 \%$ ( $n=3$ cells) (see also Laurenza et al., 1987). Rp-cAMP (100-500 $\mu \mathrm{M}$ for $40-180 \mathrm{~min}$ ) significantly reduced the effect of $20 \mu \mathrm{M}$ forskolin on mIPSC frequency $(116 \pm 5 \%$ of control in the presence of Rp-cAMP vs. $182 \%$ in untreated cultures, $p<$ 0.02 unpaired two-tailed $t$ test, $n=4$ ) (Fig. $8 C$ ). Furthermore, the forskolin derivative 1,9-dideoxyforskolin, which does not stimulate adenylyl cyclase, was found to have no effect on mIPSC frequency ( $101 \pm 9 \%$ of control, $n=3$, not shown). These data indicate that the PKA-independent actions of forskolin (Laurenza et al., 1989) did not contribute to the increase in mIPSC frequency.

The time course and magnitude of forskolin action on monosynaptic IPSCs and on mIPSC frequency were comparable to that of PDBu described above. Furthermore, the effects of forskolin were reversible (not shown).

Staurosporin blocks not only PKC, but also has a significant affinity for PKA (Rüegg and Burgess, 1989). Rp-cAMP had no effect on the ability of PDBu to increase mIPSC frequency or evoked IPSC amplitude, however ( $n=3$, not shown).

\section{Neither PDBu nor forskolin affects the kinetics of mIPSCs}

The decay of mIPSCs reflects the time course of $\mathrm{GABA}_{\mathrm{A}}$ channel closure, indicating that synaptically released transmitter binds only once to its receptors. An analysis of mIPSC kinetics, therefore, provides useful information about potential alterations of these processes by PKC or PKA. The decay of mIPSCs was well described by a single exponential $(\tau)$. There was no correlation between the amplitude of the IPSCs and their rise time or $\tau$. Neither the mIPSC decay time constants nor rise times were affected by PDBu $(n=4)$ or forskolin $(n=4)$ (Figs. 6, $5 B$, respectively). On average $\tau$ was $10.9 \pm 0.9 \mathrm{msec}$ before and after PDBu, and $12.2 \pm 0.7 \mathrm{msec}$ before and after forskolin. The rise times were $1.2 \pm 0.2 \mathrm{msec}$ before and $1.3 \pm 0.2 \mathrm{msec}$ after PDBu, and $1.8 \pm 0.1 \mathrm{msec}$ before and $1.6 \pm 0.1 \mathrm{msec}$ after forskolin. We were, thus, unable to observe any postsynaptic effects of PKC or PKA activation on synaptic $\mathrm{GABA}_{\mathrm{A}}$ receptors.

The failure to detect changes in mIPSC kinetics or amplitude after application of PDBu cannot be attributed to washout of postsynaptic PKC, as shown by the ability of PDBu to block the $\mathrm{Ca}^{2+}$-activated $\mathrm{K}^{+}$current following step depolarizations ( $n$ $=3$, not shown).

\section{The increases in MIPSC frequency are not $\mathrm{Cd}^{2+}$ sensitive}

Parfitt and Madison (1993) have recently suggested that the increase in mEPSC frequency produced by $\mathrm{PDBu}$ is mediated, in part, by a potentiation of $\mathrm{Cd}^{2+}$-sensitive voltage-dependent $\mathrm{Ca}^{2+}$ channels in the presynaptic terminal. The absence of extracellular $\mathrm{Ca}^{2+}$ does not affect the ability of phorbol esters to phosphorylate several presynaptic PKC substrate proteins (Wang et al., 1988; Dekker et al., 1989). It was, therefore, of interest to test whether PDBu or forskolin were able to increase GABA release when the presynaptic $\mathrm{Ca}^{2+}$ influx through voltage-dependent channels was blocked. Application of the inorganic $\mathrm{Ca}^{2+}$ channel antagonist $\mathrm{Cd}^{2+}$ (nominal concentration $100 \mu \mathrm{M}$ ) abolished evoked monosynaptic IPSCs but did not change the frequency or amplitude of control mIPSCs (see also Scanziani et al., 1992). Application of PDBu in the presence of $\mathrm{Cd}^{2+}$ significantly increased the frequency of mIPSCs to $216 \pm 24 \%$ of control ( $n=5$ ) (Fig. 7), not significantly different than the

\section{mIPSCs}

\section{PDBu}
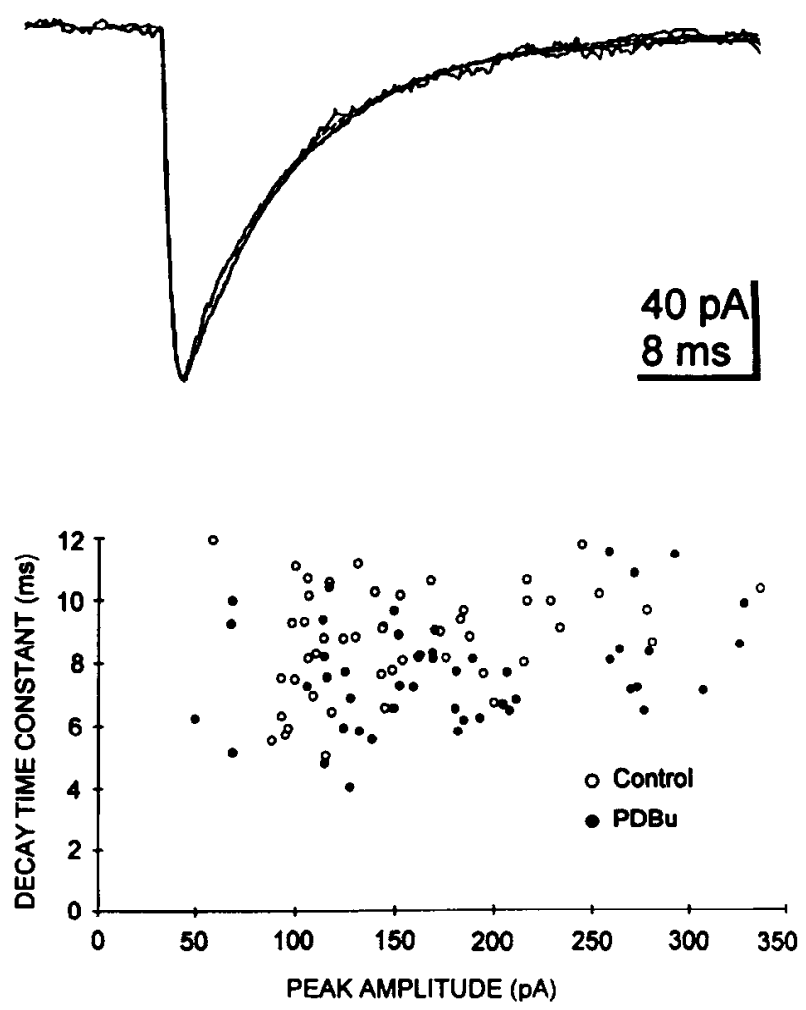

Figure 6. PDBu does not affect mIPSC kinetics. (Upper) Superimposed mIPSCs before and during $0.5 \mu \mathrm{M}$ PDBu application. Each tracc is an average of 50 mIPSCs. The decay phase of the currents is well fit with a single exponential function, the fits are shown superimposed on the mIPSCs. Fitted peak amplitude, and time constant were $147.7 \mathrm{pA}$ and $8.3 \mathrm{msec}$ before, and $148.9 \mathrm{pA}$ and $7.7 \mathrm{msec}$ during PDBu application. (Lower) Plot of the peak amplitude of individual mIPSCs against their decay time constant for the averaged mIPSCs shown at the left. Correlation before and during $\mathrm{PDBu}$ was poor $(r=0.29$ and 0.28 , respectively).

$233 \%$ increase observed in the absence of $\mathrm{Cd}^{2+}$ (see above) ( $p$ $>0.5$, unpaired two-tailed $t$ test). Similarly, application of forskolin in the presence of $\mathrm{Cd}^{2+}$ increased mIPSC frequency to a similar extent as in the absence of $\mathrm{Cd}^{2+}$ (Fig. 7). On average, forskolin increased mIPSC frequency to $207 \pm 16 \%$ of control $(n=3)$, not statistically different than in the absence of $\mathrm{Cd}^{2+}$ (182\%, see above) ( $p>0.1$, unpaired two-tailed $t$ test).

We conclude that an increase of $\mathrm{Cd}^{2+}$-sensitive voltage-dependent $\mathrm{Ca}^{2+}$ conductance at presynaptic inhibitory terminals need not contribute to the potentiating actions of phorbol esters or forskolin on spontaneous GABA release.

\section{The effects of PDBu and forskolin are additive}

Do PKC and PKA exert their actions via a common pathway? $\mathrm{PDBu}$ was found to be equally as effective in increasing the amplitude of evoked monosynaptic IPSCs and mIPSC frequency when applied after forskolin as when applied alone. Representative examples for the effect on mIPSCs and on evoked IPSCs are illustrated in Figure $8, A$ and $B$, respectively. On average, in these experiments, $20 \mu \mathrm{M}$ forskolin enhanced IPSC 
A

IPSCS CADMIUM

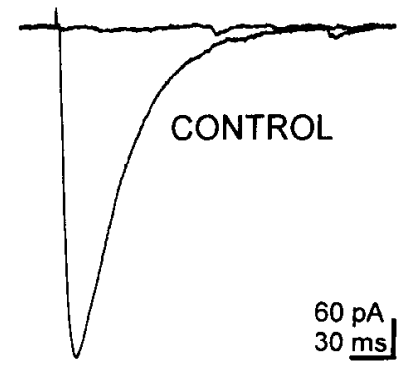

\section{mIPSCs}

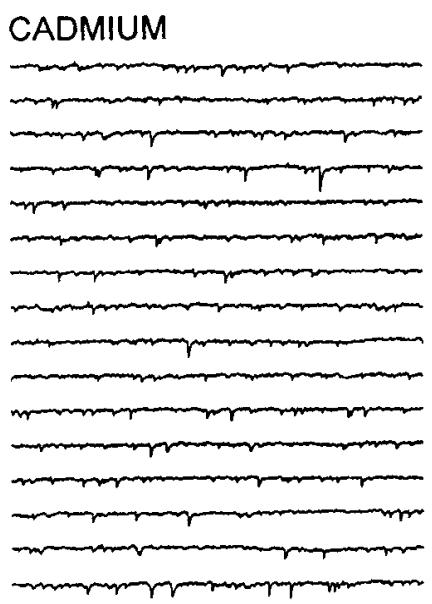

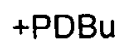

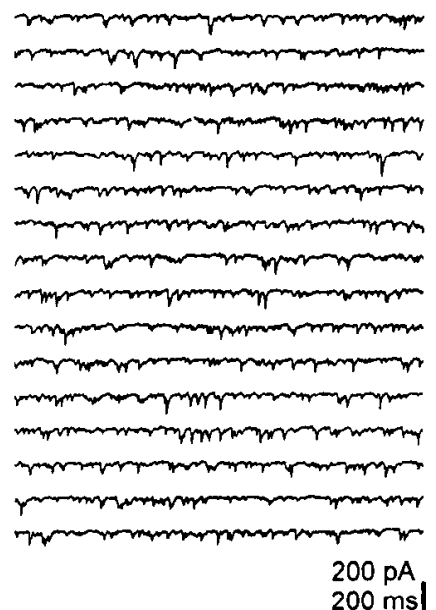

B
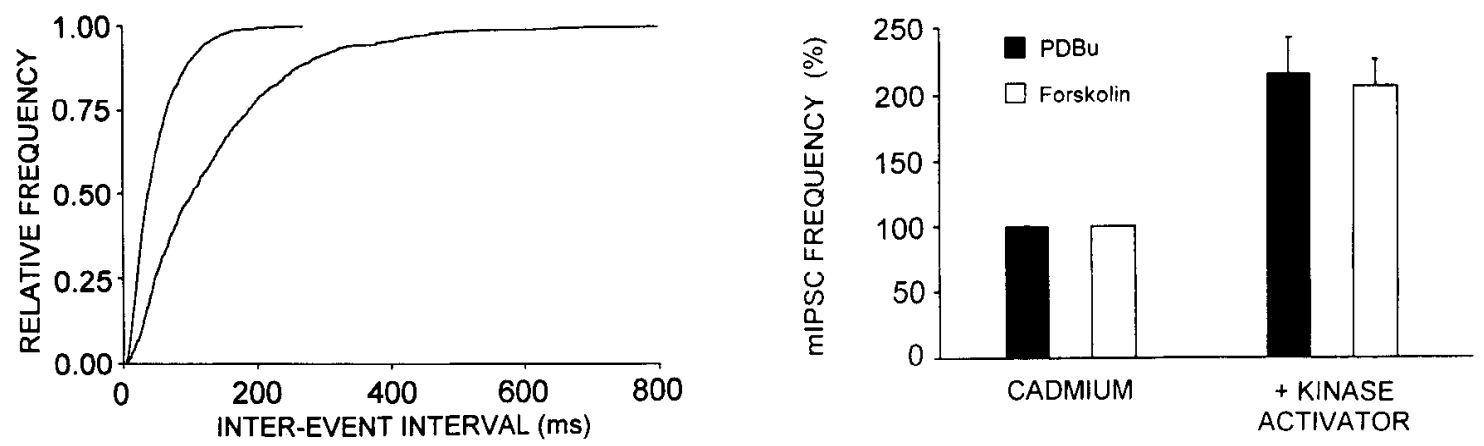

Figure 7. $\mathrm{Cd}^{2+}$ does not affect the PDBu- and forskolin-induced increase in mIPSC frequency. $A$, Application of $\mathrm{Cd}^{2+}(100 \mu \mathrm{M})$ abolished monosynaptic GABA receptor-mediated IPSCs (left). The frequency of mIPSCs in the same cell (right, after addition of $0.5 \mu \mathrm{M}$ TTX) was increased from $7.4 \mathrm{~Hz}$ to $20.6 \mathrm{~Hz}$ by application of $0.5 \mu \mathrm{M} \mathrm{PDBu}$ in the continued presence of $100 \mu \mathrm{M} \mathrm{Cd}{ }^{2+}$. The cumulative interevent interval distribution for mIPSCs in this cell is shown below (left). In the presence of $\mathrm{Cd}^{2+}, \mathrm{PDBu}$ shifted this relation to the left toward shorter interevent intervals (number of events analyzed $=752$ and 2105 ). The mean amplitude was unchanged, however $(39.3 \mathrm{pA}$ and $41.1 \mathrm{pA}, p>0.05$, KolmogorovSmimov test). B, Pooled data showing that both kinase activators PDBu (filled bars) and forskolin (open bars) increase mIPSC frequency in the presence of $\mathrm{Cd}^{2+}(n=5$ and 3 , respectively).

amplitude to $191 \pm 13 \%$ of control and subsequent application of $0.5 \mu \mathrm{M}$ PDBu further enhanced IPSC amplitude by $222 \pm$ $37 \%(n=3)$. Similarly, when forskolin had already increased mIPSC frequency to $186 \pm 6 \%$ of the control, subsequent application of PDBu elicited a further increase of $234 \pm 18 \%$ ( $n$ $=4$ ). These effects were, thus, quantitatively comparable to those induced by each of the two kinases stimulator applied alone (Fig. $8 C$ ). Similar results were also obtained by applying forskolin after PDBu (not shown).

\section{Discussion}

We find that both phorbol esters and forskolin greatly enhance GABA release from axon terminals of inhibitory interneurons in area CA 3 through activation of $\mathrm{PKC}$ and $\mathrm{PKA}$, respectively. Preliminary evidence of a potentiation of evoked $\mathrm{GABA}_{\mathrm{A}}$ receptor-mediated responses at hippocampal synapses has previously been reported (Lambert and Teyler, 1991; Pitler and Alger, 1992), and may, in retrospect, be seen in studies of the action of phorbol esters at excitatory synapses (Malenka et al., 1987; Segal, 1989; Agopyan et al., 1993). Stimulation of PKA has also been shown to potentiate both evoked and spontaneous release of glutamate in the hippocampus (Chavez-Noriega and Stevens, 1994). The quantitative analysis of mIPSCs shows clearly that both PDBu and forskolin increase their frequency only, and not their amplitude, rise time, or decay time, indicating a purely presynaptic mechanism of action, as also established for the action of phorbol esters on hippocampal excitatory synaptic transmission (Malenka et al., 1986, 1987; Yamamoto et al., 1987; Finch and Jackson, 1990; Parfitt and Madison, 1993). Furthermore, PDBu has no effect on responses to exogenous GABA or on the reversal potential of evoked monosynaptic IPSCs.

Several subunits of the $\mathrm{GABA}_{\mathrm{A}}$ receptor exhibit consensus sequences for phosphorylation by PKC and PKA, and evidence for a role of the PKA- and PKC-dependent phosphorylation of $\mathrm{GABA}_{\mathrm{A}}$ receptors has been reported in other systems (for review, sec Raymond ct al., 1993). We did not find evidence of PKA or PKC-induced modulation of pyramidal cell $\mathrm{GABA}_{\mathrm{A}}$ receptors. We cannot fully exclude that the lack of effects on postsynaptic $\mathrm{GABA}_{\mathrm{A}}$ receptors results from intracellular dialysis; 
A mIPSCs

\section{CONTROL}
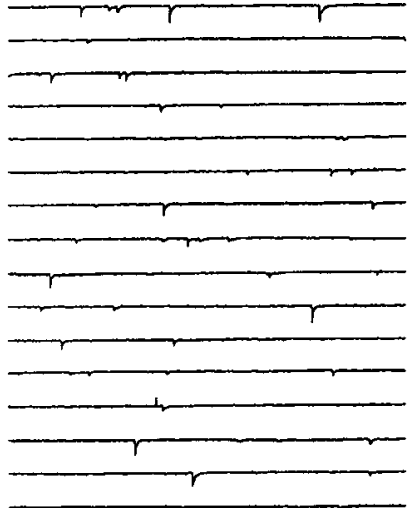

B MONOSYNAPTIC IPSCs

\section{FORSKOLIN}

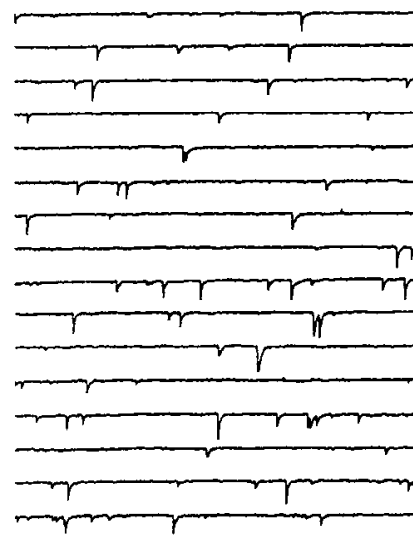

C
$+\mathrm{PDBu}$

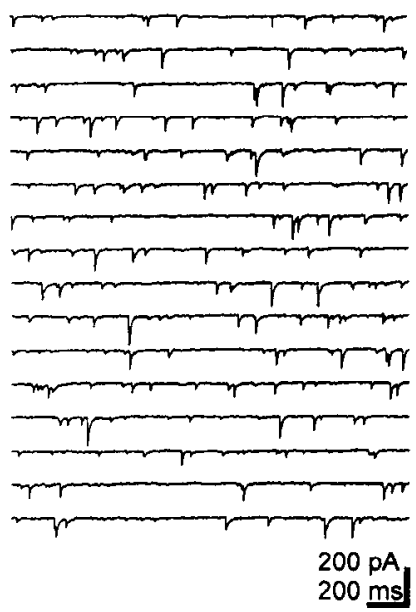

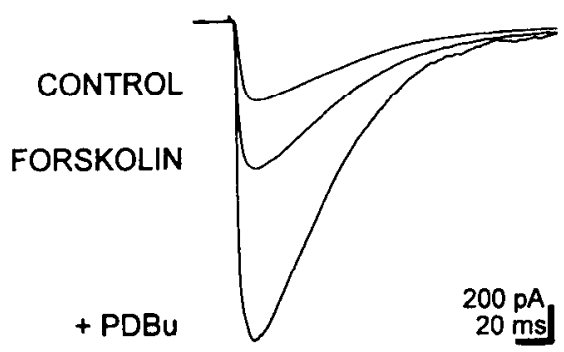

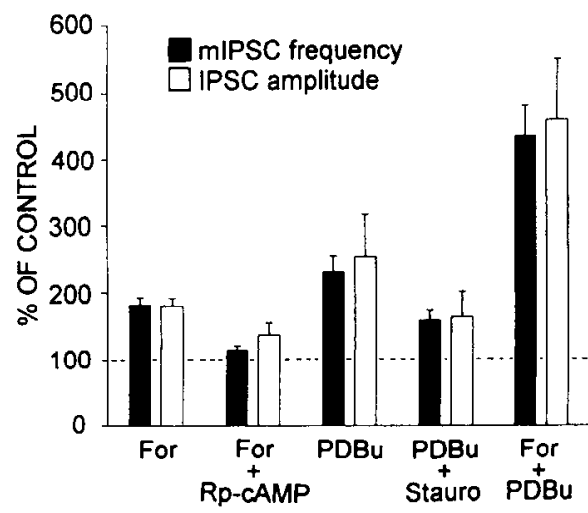

Figure 8. The effects of forskolin and $\mathrm{PDBu}$ on inhibitory synaptic transmission are additive. $A$, Each panel depicts continuously recorded GABA receptor-mediated mIPSCs. mIPSC frequency was increased during application of $20 \mu \mathrm{M}$ forskolin from $1.2 \mathrm{~Hz}$, and reached a steady-state frequency of $2.5 \mathrm{~Hz}$. Addition of $0.5 \mu \mathrm{M}$ PDBu then further increased mIPSC frequency to $6.2 \mathrm{~Hz}$. Mean mIPSC amplitude was not significantly different throughout ( $p>0.09$ and $p>0.4$, Kolmogorov-Smirnov test). $B$, Evoked monosynaptic IPSCs were enhanced by $20 \mu \mathrm{M}$ forskolin and subsequent application of $0.5 \mu \mathrm{M}$ PDBu. KCl-containing electrode, holding potential $=-70 \mathrm{mV}$. C, Pooled data showing the effects of forskolin $(F o r)$ or/and PDBu on mIPSC frequency ( filled columns) and monosynaptic IPSC amplitude (open columns), in the presence and absence of the kinase antagonists Rp-cAMP or staurosporin (Stauro), respectively (from the left, $n=10$ and 6, 4 and 4, 19 and 6,10 and 4,4 and 3).

however, $\mathrm{PDBu}$ potently reduced the $\mathrm{Ca}^{2}$ - -aclivated $\mathrm{K}^{+}$current underlying the afterhyperpolarization, even when recorded in the whole-cell mode. In addition, stimulation of PKA has been shown to reduce GABA responses in whole-cell recordings from mouse spinal neurons as a result of a modification in the gating of $\mathrm{GABA}_{\mathrm{A}}$ receptor-gated $\mathrm{Cl}^{-}$channels that promotes long-lasting closed states (Porter et al., 1990). mIPSCs in CA3 pyramidal cells exhibit a single monoexponential decay, which may correspond to the shorter duration, PKA-insensitive closed state in mouse spinal cells. The lack of a second slower decay phase for mIPSCs in CA3 cells may indicate that pyramidal cell

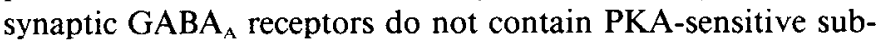
units (Whiting et al., 1990).

Do the effects of kinase activation on evoked and spontaneous release result from a single mechanism of action?

This question is difficult to answer because the two types of release differ in one key respect: evoked release requires voltagedependent $\mathrm{Ca}^{2+}$ influx, whereas action-potential independent release does not. The quantal release hypothesis states, however, that $\mathrm{Ca}^{2+}$ influx serves only to increase the probability that single vesicles fuse with the presynaptic membrane, thus resulting in the synchronized release of large numbers of vesicles in the case of the neuromuscular junction. In the mammalian CNS, on the other hand, there is increasing evidence that evoked synaptic transmission results from the release of only one or very few vesicles per release site (e.g., Perkel and Nicoll, 1993). It, thus, seems likely that the pool of vesicles participating in spontaneous and evoked release is the same.

We have found no evidence in our experiments that suggests that the mechanism underlying the two effects might be different. On the contrary, in every experiment performed, we have observed that the changes in the amplitude of evoked IPSCs and the frequency of mIPSCs were quantitatively comparable (Fig. $8 C$ ). First, the mean increases in mIPSC frequency produced by $\mathrm{PDBu}(233 \%$ of control) and forskolin $(182 \%)$ were almost identical to the mean increases in evoked IPSC peak amplitude $(256 \%$ and $180 \%)$. Second, the time course of both effects of PDBu and forskolin were comparable (Fig. 3). Third, both effects of $\mathrm{PDBu}$ were reduced by staurosporin to a similar extent. Fi- 
nally, the effects of the kinase activators on both forms of release were additive to a strikingly similar degree. These observations support the hypothesis that the facilitation of spontaneous and evoked GABA release results from a common mechanism. The actions of the two kinases, on the other hand, appear to be mediated via phosphorylation of different substrates (see below).

Potentiation of evoked and spontaneous transmitter release via a common mechanism is also consistent with the parallel increase in the frequency of miniature endplate potentials and the amplitude of evoked endplate potentials observed at the neuromuscular junction after extracellular application of phorbol ester (Shapira et al., 1987; D'Angelo et al., 1992) or ethanol (Quastel et al., 1971), as well as the decrcases in both forms of release produced by intracellular injection of antibodies to synaptophysin into the presynaptic cell (Alder et al., 1992). Likewise, we have previously reported that activation of some presynaptic receptors produces quantitatively similar decreases in evoked response amplitude and miniature response frequency (Scanziani et al., 1992; Capogna et al., 1993a). Nevertheless, there are manipulations that produce dissimilar changes in the frequency of miniature currents and the amplitude of evoked responses (e.g., Littleton et al., 1993; DiAntonio and Schwarz, 1994).

\section{By what mechanism do $P K A$ and $P K C$ potentiate $G A B A$ release?}

In principle, kinase activity might affect any component in stimulus-secretion coupling from $\mathrm{Ca}^{2+}$ entry to exocytosis. The deduced amino acid scquences of several subunits of voltage-dependent $\mathrm{Ca}^{2+}$ channels contain putative sites for phosphorylation by PKC and PKA (e.g., Williams et al., 1992). Indeed, activation of at least $\mathrm{PKC}$ has been shown to modulate $\mathrm{Ca}^{2+}$ channel gating in the nervous system, including potentiation of high threshold $\mathrm{Ca}^{2+}$ currents in hippocampal pyramidal neurons (O'Dell and Alger, 1991; Swartz et al., 1993). In agreement with other studies at excitatory synapses (Malenka et al., 1987; Finch and Jackson, 1990), however, we find that an enhancement of $\mathrm{Ca}^{2+}$ influx at inhibitory terminals is not required for potentiation of spontaneous presynaptic GABA release, as shown by the inability of the $\mathrm{Ca}^{2+}$ channel blocker $\mathrm{Cd}^{2+}$ to affect the actions of PDBu and forskolin on mIPSC frequency. This result indicates that at least one form of potentiation can occur at some point subsequent to voltage-dependent $\mathrm{Ca}^{2+}$ influx. Parfitt and Madison (1993), using slightly different recording conditions, have reported that a portion of the increase in mEPSC frequency produced by higher concentrations of phorbol esters is attenuated by $\mathrm{Cd}^{2+}$, but that a two- to threefold increase in mEPSC frequency persists after blocking $\mathrm{Ca}^{2+}$ influx, comparable to the increase in $\mathrm{mIPSC}$ frequency we report here. If $\mathrm{PKC}$-induced potentiation of $\mathrm{Ca}^{2+}$ influx also occurs, it could only contribute to potentiation of evoked, but not spontaneous, release in our experiments.

The biochemistry of the exocytotic process has been characterized in great detail with the recent identification of numerous proteins believed to be involved in anchoring vesicles to cytoskeletal elements, targeting vesicles to the presynaptic membrane, docking vesicles in the vicinity of $\mathrm{Ca}^{2+}$ channels, and forming fusion pores. Several of these proteins possess putative sites for phosphorylation by PKC or PKA, and these may be divided into two classes: proteins associated with the cytoskeleton (e.g., synapsin, GAP-43, MARCKS, dynamin) (Apel and Storm, 1992; Hartwig et al., 1992; Greengard et al., 1993;
Robinson et al., 1993) or proteins involved in the interaction of synaptic vesicles with the presynaptic membrane (e.g., $\alpha$-SNAP, SNAP-25) (Oyler et al., 1989; Whiteheart et al., 1993). Phosphorylation of any of these proteins could potentiate spontaneous and evoked transmitter release 'downstream' of $\mathrm{Ca}^{2+}$ influx.

Among the cytoskeletal-associated proteins, the synapsins are a prominent substrate for PKA in the axon terminal, and there is evidence that their phosphorylation is associated with a potentiation of transmitter release (for review, see Greengard et al., 1993). Antibodies directed against another presynaptic PKC substrate, GAP-43 (or B-50), are reported to inhibit transmitter rclease; however, they do not block the potentiation of norepinephrine release from cortical synaptosomes induced by phorbol ester (Dekker et al., 1991). Phosphorylation of any of this class of proteins might cause mobilization of vesicles from the cytoskeleton and increase the number of vesicles available for either evoked or spontaneous release, in the absence of any change in the exocytotic process itself.

The presence of consensus sequences for phosphorylation by PKA in SNAP-25, and for phosphorylation by PKC in SNAP25 and the predominant brain SNAP isoform, $\alpha$-SNAP, offers potential sites for a direct interaction of protein kinases with the cellular 'machinery' required for exocytosis (Söllner et al., 1993). Unfortunately, the functional consequences of phosphorylation of these proteins is not yet known. One may speculate, however, that phosphorylation at these sites might result in a change in the $\mathrm{Ca}^{2+}$ sensitivity of exocytosis so that both evoked and spontaneous release would be potentiated, even in the absence of changes in basal $\mathrm{Ca}^{2+}$ concentration or voltagedependent $\mathrm{Ca}^{2+}$ influx.

Clearly, a causal relationship between intraterminal protein kinase stimulation, phosphorylation of a specific protein, and consequent facilitation of neurotransmitter release remains to be established. Interestingly, our finding that the effects of PDBu and forskolin on both evoked and miniature IPSCs are additive (Fig. 8), suggests to us that PKA and PKC can potentiate GABA release from interneurons via two independent mechanisms. For example, one kinase might facilitate vesicle mobilization while the other potentiates exocytosis. A facilitation of evoked transmitter release produced by the parallel actions of the two kinases has also been described in Aplysia, although PKA apparently does not affect spontaneous release in this system (Ghirardi et al., 1992). The existence of multiple phosphorylation sites that facilitate transmitter release suggests that different forms of presynaptic plasticity might utilize different mechanisms.

Inhibitory synaptic transmission is subject to a number of modulatory influences, most of which result in a decrease in its efficacy. For example, numerous presynaptic receptors are localized on the axon terminals of interneurons and act to decrease GABA release (Thompson et al., 1993). Potentiation of synaptic inhibition has not been demonstrated in the hippocampus. Excitatory synaptic transmission, in contrast, is subject to both presynaptic inhibition and short- and long-term potentiation. In the cerebellum, PKA is activated by stimulation of $\beta$-adrenergic receptors, resulting in an increase in the frequency of mIPSCs (Llano and Gerschenfeld, 1993). Although $\beta$-adrenergic receptors do not modulate presynaptic GABA release in the hippocampus (Doze et al., 1991), we have demonstrated that the cellular machinery necessary for potentiating GABA release exists. The regulatory influences that activate these processes remain to be established. 


\section{References}

Agopyan N, Miu P, Krnjevic K (1993) Modulation of high-threshold Ca current and spontaneous postsynaptic transient currents by phorbol 12, 13-diacetate, 1-(5-isoquinolinesulfonyl)-2-methyl piperazine (H7), and monosialoganglioside (GM1) in CAl pyramidal neurons of rat hippocampus in vitro. Hippocampus 3:67-76.

Alder J, Xie Z-P, Valtorta F, Greengard P, Poo M-M (1992) Antibodies to synaptophysin interfere with transmitter secretion at neuromuscular synapscs. Ncuron 9:759-768.

Apel ED, Storm DR (1992) Functional domains of neuromodulin (GAP-43). Perspect Dev Biol 1:3-11.

Cadd G, McKnight GS (1989) Distinct patterns of cAMP-dependent protein kinase expression in mouse brain. Neuron 3:71-79.

Capogna M, Gähwiler BH, Thompson, SM (1993a) Mechanism of $\mu$-opioid receptor-mediated presynaptic inhibition in the rat hippocampus in vitro. J Physiol (Lond) 470:539-558.

Capogna M, Gähwiler BH, Thompson SM (1993b) Stimulation of protein kinase $\mathrm{C}$ increases inhibitory synaptic transmission in the rat hippocampus. Soc Neurosci Abstr 19:902.

Chavez-Noriega LE, Stevens CF (1994) Increased transmitter release at excitatory synapses produced by direct activation of adenylate cyclase in rat hippocampal slices. J Neurosci 14:310-317.

D'Angclo E, Rossi P, Tanzi F, Taglietti V (1992) Protein kinase C facilitation of acetylcholine release at the rat neuromuscular junction. Eur J Neurosci 4:823-831.

Davies CH, Davies SN, Collingridge GL (1990) Paired-pulse depression of monosynaptic GABA-mediated inhibitory postsynaptic responses in rat hippocampus. J Physiol (Lond) 424:513-531.

Dekker LV, De Graan PNE, Versteeg DHG, Oestreicher AB, Gispen WH (1989) Phosphorylation of B-50 (GAP43) is correlated with neurotransmitter release in rat hippocampal slices. J Neurochem 52: 24-30.

Dekker LV, De Graan PNE, Pijnappel P, Oestreicher AB, Gispen WH (1991) Noradrenaline release from streptolysin O-permeated rat cortical synaptosomes: effects of calcium, phorbol esters, protein kinase inhibitors, and antibodies to the neuron-specific protein kinase $\mathrm{C}$ substrate B-50 (GAP-43). J Neurochem 56:1146-1153.

DiAntonio A, Schwarz TL (1994) The effect on synaptic physiology of synaptotagmin mutations in Drosophila. Neuron 12:909-920.

Doze VA, Cohen GA, Madison DV (1991) Synaptic localization of adrenergic disinhibition in the rat hippocampus. Neuron 6:889-900.

Dutar P, Nicoll RA (1988) Pre- and postsynaptic GABA B $_{\mathrm{B}}$ receptors in the hippocampus have different pharmacological properties. Neuron 1:585-591.

Finch DM, Jackson MB (1990) Presynaptic enhancement of synaptic transmission in hippocampal cell cultures by phorbol esters. Brain Res 518:269-273.

Gähwiler BH (1981) Organotypic monolayer cultures of nervous tissue. J Neurosci Methods 4:329-342.

Gähwiler BH, Thompson SM, Audinat E, Robertson RT (1991) Organotypic slice cultures of neural tissue. In: Culturing nerve cells (Banker G, Goslin K, eds), pp 379-411. Cambridge, MA: MIT Press.

Gehlert DR, Dawson TM, Yamamura HI, Wamsley JK (1985) Quantitative autoradiography of $\left[{ }^{3} \mathrm{H}\right]$ forskolin binding sites in the rat brain. Brain Res 361:351-360.

Ghirardi M, Braha O, Hochner B, Montarolo PG, Kandel ER, Dale N (1992) Roles of PKA and PKC in facilitation of evoked and spontaneous transmitter release at depressed and nondepressed synapses in Aplysia sensory neurons. Neuron 9:479-489.

Greengard P, Valtorta F, Czernik AJ, Benfenati F (1993) Synaptic vesicle phosphoproteins and regulation of synaptic function. Science 259:780-785.

Hartwig JH, Thelen M, Rosen A, Janmey PA, Nairn AC, Aderem A (1992) MARCKS is an actin filament crosslinking protein regulated by protein kinase $C$ and calcium-calmodulin. Nature 356:618-622.

Hopkins WF, Johnston D (1988) Noradrenergic enhancement of longterm potentiation at mossy fiber synapses in the hippocampus. $J$ Neurophysiol 59:667-687.

Kraft AS, Anderson WB (1983) Phorbol esters increase the amount of $\mathrm{Ca}^{2+}$, phospholipid-dependent protein kinase associated with plasma membrane. Nature 301:621-623.

Lambert NA, Teyler TJ (1991) Cholinergic disinhibition in area CA1 of the rat hippocampus is not mediated by receptors located on inhibitory neurons. Eur J Pharmacol 203:129-131.
Laurenza A, Khandelwal Y, De Souza NJ, Rupp RH, Metzger H, Seamon KB (1987) Stimulation of adenylate cyclase by water-soluble analogues of forskolin. Mol Pharmacol 32:133-139.

Laurenza A, Sutkowski EM, Seamon KB (1989) Forskolin: a specific stimulator of adenylyl cyclase or a diterpene with multiple sites of action? Trends Pharmacol Sci 10:442-447.

I ittleton JT, Stern M, Schulze K, Perin M, Bellen HJ (1993) Mutational analysis of Drosophila synaptotagmin demonstrates its essentia role in $\mathrm{Ca}^{2+}$-activated neurotransmitter release. Cell 74:1125-1134.

Llano I, Gerschenfeld HM (1993) $\beta$-Adrenergic enhancement of inhibitory synaptic activity in rat cerebellar stellate and purkinje cells. J Physiol (Lond) 468:201-224.

Malenka RC, Nicoll RA (1993) NMDA-receptor-dependent synaptic plasticity: multiple forms and mechanisms. Trends Neurosci 16:521527.

Malenka KC, Madison DV, Nicoll RA (1986) Potentiation of synaptic transmission in the hippocampus by phorbol esters. Nature 321:175177.

Malenka RC, Ayoub GS, Nicoll RA (1987) Phorbol esters enhance transmitter release in rat hippocampal slices. Brain Res 403:198-203.

McGinty JF, Couce MF, Bohler WT, Ways KD (1991) Protein kinase $\mathrm{C}$ subspecies distinguish major cell types in rat hippocampus: an immunocytochemical and in situ hybridization histochemical study. Hippocampus 1:293-302.

Nishizuka Y (1988) The molecular heterogeneity of protein kinase C and its implications for cellular regulation. Nature 334:661-665.

O'Dell TJ, Alger BE (1991) Single calcium channels in rat and guineapig hippocampal neurons. J Physiol (Lond) 436:739-767.

Oyler GA, Higgins GA, Hart RA, Battenberg E, Billingsley M, Bloom $\mathrm{FE}$, Wilson MC (1989) The identification of a novel synaptosomalassociated protein, SNAP-25, differentially expressed by neuronal subpopulations. J Cell Biol 109:3039-3052.

Parfitt KD, Madison DV (1993) Phorbol esters enhance synaptic transmission by a presynaptic, calcium-dependent mechanism in rat hippocampus. J Physiol 471:245-268.

Perkel DJ, Nicoll RA (1993) Evidence for all-or-none regulation of neurotransmitter release: implications for long-term potentiation. J Physiol (Lond) 471:481-500.

Pitler TA, Alger BE (1992) Phorbol esters enhance monosynaptic IPSCs in rat hippocampal pyramidal cells. Soc Neurosci Abstr 18: 792.

Porter NM, Twyman RE, Uhler MD, Macdonald RL (1990) Cyclic AMP-dependent protein kinase decreases $\mathrm{GABA}_{\mathrm{A}}$ receptor current in mouse spinal neurons. Neuron 5:789-796.

Quastel DMJ, Hackett JT, Cooke JD (1971) Calcium: is it required for transmitter secretion? Science 172:1034-1036.

Raymond LA, Blackstone CD, Huganir RL (1993) Phosphorylation of amino acid neurotransmitter receptors in synaptic plasticity. Trends Neurosci 16:147-153.

Robinson PJ, Sontag J-M, Liu J-P, Fykse EM, Slaughter C, McMahon $\mathrm{H}$, Südhof TC (1993) Dynamin GTPase regulated by protein kinase C phosphorylation in nerve terminals. Nature 365:163-166.

Rothermel JD, Botelho LHP (1988) A mechanistic and kinetic analysis of the interactions of the diastereoisomers of adenosine $3^{\prime}, 5^{\prime}$-(cyclic) phosphorothioate. Biochem J 251:757-762.

Rüegg UT, Burgess GM (1989) Staurosporine, K-252 and UCN-01: potent but nonspecific inhibitors of protein kinases. Trends Pharmacol Sci 10:218-220.

Scanziani M, Capogna M, Gähwiler BH, Thompson SM (1992) Presynaptic inhibition of miniature excitatory synaptic currents by baclofen and adenosine in the hippocampus. Neuron 9:919-927.

Segal M (1989) Synaptic transmission between cultured rat hippocampal neurons is enhanced by activation of protein kinase-C. Neurosci Lett 101:169-174.

Shapira R, Silberberg SD, Ginsburg S, Rahamimoff R (1987) Activation of protein kinase $\mathrm{C}$ augments evoked transmitter release. $\mathrm{Na}$ ture 325:58-60.

Sim JA, Gerber U, Knöpfel T, Brown DA (1992) Evidence against a role for protein kinase $C$ in the inhibition of the calcium-activated potassium current $I_{\text {AHP }}$ by muscarinic stimulants in rat hippocampal neurons. Eur J Neurosci 4:785-791.

Söllner T, Bennett MK, Whiteheart SW, Scheller RH, Rothman JE (1993) A protein assembly-disassembly pathway in vitro that may correspond to sequential steps of synaptic vesicle docking, activation, and fusion. Cell 75:409-418. 
Streit P, Thompson SM, Gähwiler BH (1989) Anatomical and physiological properties of GABAergic neurotransmission in organotypic slice cultures of rat hippocampus. Eur J Neurosci 1:603-615.

Swartz KJ, Merritt A, Bean BP, Lovinger DM (1993) Protein kinase $\mathrm{C}$ modulates glutamate receptor inhibition of $\mathrm{Ca}^{2+}$ channels and synaptic transmission. Nature 361:165-168.

Thompson SM, Capogna M, Scanziani M (1993) Presynaptic inhibition in the hippocampus. Trends Neurosci 16:222-227.

Tokumitsu H, Chijiwa T, Hagiwara M, Mizutani A, Terasawa M, Hidaka $\mathrm{H}$ (1990) $\mathrm{KN}$-62, 1-[N,O-Bis(5-isoquinolinesulfonyl)- $N$-methyl-L-tyrosyl]-4-phenylpiperazine, a specific inhibitor of $\mathrm{Ca}^{2+} /$ calmodulin-dependent protein kinase II. J Biol Chem 265:4315-4320.

Van Der Kloot W (1991) The regulation of quantal size. Prog Neurobiol 36:93-130.

Wang JKT, Walaas SI, Greengard P (1988) Protein phosphorylation in nerve terminals: comparison of calcium/calmodulin-dependent and calcium/diacylglycerol-dependent systems. J Neurosci 8:281-288.

Weisskopf MG, Zalutsky RA, Nicoll RA (1993) Cyclic-AMP-mediated enhancement and LTP at mossy fiber synapses in the hippocampus. Soc Neurosci Abstr 19:1708.
Whiteheart SW, Griff IC, Brunner M, Clary DO, Mayer T, Buhrow SA, Rothman JE (1993) SNAP family of NSF attachment proteins includes a brain-specific isoform. Nature 362:353-355.

Whiting P, McKernan RM, Iversen LL (1990) Another mechanism for creating diversity in $\gamma$-aminobutyrate type A receptors: RNA splicing directs expression of two forms of $\gamma 2$ subunit, one of which contains a protein kinase C phosphorylation site. Proc Natl Acad Sci USA 87:9966-9970.

Wilkinson SE, Hallam TJ (1994) Protein kinase C: is its pivotal role in cellular activation over-stated? Trends Pharmacol Sci 15:53-57.

Williams ME, Brust PF, Feldman DH, Patthi S, Simerson S, Maroufi A, McCue AF, Brenner R, Veliçelebi G, Ellis SB, Harpold MM (1992) Structure and functional expression of an $\omega$-conotoxin-sensitive human N-type calcium channel. Science 257:389-395.

Worley PF, Baraban JM, Snyder SH (1986) Heterogeneous localization of protein kinase $\mathrm{C}$ in rat brain: autoradiographic analysis of phorbol ester receptor binding. J Neurosci 6:199-207.

Yamamoto C, Higashima M, Sawada S (1987) Quantal analysis of potentiating action of phorbol ester on synaptic transmission in the hippocampus. Neurosci Res 5:28-38. 